\title{
Purification and Partial Characterization of Thermostable Serine Alkaline Protease from a Newly Isolated Bacillus subtilis PE-11
}

Submitted: June 4, 2003; Accepted: August 19, 2003

Kunamneni Adinarayana, ${ }^{1}$ Poluri Ellaiah, ${ }^{1}$ and Davuluri Siva Prasad ${ }^{2}$

${ }^{1}$ Pharmaceutical Biotechnology Division, Department of Pharmaceutical Sciences, Andhra University, Visakhapatnam, India

${ }^{2}$ Department of Biochemistry, Andhra University, Visakhapatnam, India

\section{ABSTRACT}

The purpose of the research was to study the purification and partial characterization of thermostable serine alkaline protease from a newly isolated Bacillus subtilis PE-11. The enzyme was purified in a 2-step procedure involving ammonium sulfate precipitation and Sephadex G-200 gel permeation chromatography. The enzyme was shown to have a relative low molecular weight of $15 \mathrm{kd}$ by sodium dodecyl sulphate polyacrylamide gel electrophoresis (SDS-PAGE) and was purified 21 -fold with a yield of $7.5 \%$. It was most active at $60^{\circ} \mathrm{C}, \mathrm{pH} 10$, with casein as substrate. It was stable between $\mathrm{pH} 8$ and 10 . This enzyme was almost $100 \%$ stable at $60^{\circ} \mathrm{C}$ even after 350 minutes of incubation. It was strongly activated by metal ions such as $\mathrm{Ca}^{+2}, \mathrm{Mg}^{+2}$, and $\mathrm{Mn}^{+2}$. Enzyme activity was inhibited strongly by phenylmethyl sulphonyl fluoride (PMSF) and diisopropyl fluorophosphates (DFP) but was not inhibited by ethylene diamine tetra acetic acid (EDTA), while a slight inhibition was observed with iodoacetate, $p$-chloromercuric benzoate $(p \mathrm{CMB})$, and $\beta$ mercaptoethanol ( $\beta-\mathrm{ME})$. The compatibility of the enzyme was studied with commercial and local detergents in the presence of $10 \mathrm{mM} \mathrm{CaCl}_{2}$ and $1 \mathrm{M}$ glycine. The addition of $10 \mathrm{mM} \mathrm{CaCl}_{2}$ and $1 \mathrm{M}$ glycine, individually and in combination, was found to be very effective in improving the enzyme stability where it retained 52\% activity even after 3 hours. This enzyme improved the cleansing power of various detergents. It removed blood stains completely when used with detergents in the presence of $10 \mathrm{mM} \mathrm{CaCl} 2$ and $1 \mathrm{M}$ glycine.

Corresponding Author: Poluri Ellaiah, Pharmaceutical Biotechnology Division, Department of Pharmaceutical Sciences, Andhra University, Visakhapatnam, India, 530 003. Fax: +91-891-2755547; Email: adikunamneni@rediffmail.com
KEYWORDS: alkaline protease, Bacillus subtilis, PE11, purification, characterization, compatibility

\section{INTRODUCTION}

Proteases are one of the most important industrial enzymes accounting for nearly $60 \%$ of the total worldwide enzyme sales. ${ }^{1-6}$ Of these, alkaline proteases are employed primarily as cleansing additives. Among the various proteases, bacterial proteases are the most significant, compared with animal and fungal proteases. ${ }^{1}$ Ideally, proteases used in a detergent formulation should have a high level of activity over a broad range of $\mathrm{pH}$ and temperatures. Alkaline proteases from high yielding strains have been studied extensively. One of the major drawbacks affecting the stability at alkaline $\mathrm{pH}$ of enzymes recovered from thermophiles is that enzymes from alkalophiles confer stability in a wide pH range but are usually thermolabile. ${ }^{7}$ Thus it is desirable to search for new proteases with novel properties from as many different sources as possible. In the present study we examined the efficiency of an enzyme, recovered from a newly isolated strain of Bacillus subtilis PE-11, in the presence of standard commercial detergents. Further, characterization of this enzyme and the effect of various cofactors or additives on the stability at higher temperatures and in alkaline $\mathrm{pH}$ were carried out. The enzyme has been used as an effective additive for the laundry industry and can be exploited commercially.

\section{MATERIALS AND METHODS}

\section{Isolation and Cultivation of Microorganisms}

The soil samples were collected from sandy soil, milk processing plant, the drainage of a slaughterhouse, the beds of an effluent treatment plant, etc, of Visakhapatnam, India, and were diluted in sterile saline solution. 


\section{AAPS PharmSciTech 2003; 4 (4) Article 56 (http://www.aapspharmscitech.org).}

The diluted samples were plated onto skim milk agar plates containing peptone $(0.1 \% \mathrm{wt} / \mathrm{vol}), \mathrm{NaCl}(0.5 \%$ $\mathrm{wt} / \mathrm{vol})$, agar $(2.0 \% \mathrm{wt} / \mathrm{vol})$, and skim milk (10\% $\mathrm{vol} / \mathrm{vol})$. Plates were incubated at $37^{\circ} \mathrm{C}$ for 24 hours. A clear zone of skim milk hydrolysis gave an indication of protease producing organisms. Depending upon the zone of clearance, strain PE-11 was selected for further experimental studies. The isolated proteolytic strain was a spore-forming gram-positive rod, identified as $B$ subtilis, and $\mathrm{it}^{8-9}$ was designated as $B$ subtilis PE-11.

Production of protease from $B$ subtilis PE-11 was carried out in a medium containing the following: glucose, $0.5 \%$ (wt/vol); peptone, $0.75 \%$ (wt $/ \mathrm{vol}$ ); and salt solution, $5 \% \quad(\mathrm{vol} / \mathrm{vol}) \quad\left(\mathrm{MgSO}_{4} .7 \mathrm{H}_{2} \mathrm{O}, 0.5 \% \quad[\mathrm{wt} / \mathrm{vol}]\right.$; $\mathrm{KH}_{2} \mathrm{PO}_{4}, 0.5 \%$ [wt/vol]; and $\mathrm{FeSO}_{4} .7 \mathrm{H}_{2} \mathrm{O}, 0.01 \%$ [wt/vol]) and maintained at $37^{\circ} \mathrm{C}$ for 48 hours in a shaker incubator $(140 \mathrm{rpm})$. The $\mathrm{pH}$ of the medium was adjusted with $1 \mathrm{~N} \mathrm{NaOH}$ or $1 \mathrm{~N} \mathrm{HCl}$. After the completion of fermentation, the whole fermentation broth was centrifuged using Sorvall RC5C centrifuge (Sorvall, New Delhi, India) at $10000 \mathrm{rpm}$ at $4^{\circ} \mathrm{C}$, and the clear supernatant was recovered. The crude enzyme supernatant was subjected to further studies.

\section{Enzyme Purification}

\section{Ammonium Sulphate Precipitation}

The organism was grown for 48 hours as described previously. The cells were separated by centrifugation (10 $000 \mathrm{rpm}, 15$ minutes), and the supernatant was fractionated by precipitation with ammonium sulfate between $50 \%$ and $70 \%$ of saturation. All subsequent steps were carried out at $4^{\circ} \mathrm{C}$. The protein was resuspended in $0.1 \mathrm{M}$ Tris-HCl buffer, $\mathrm{pH} 7.8$, and dialyzed against the same buffer.

\section{Sephadex G-200 Gel Filtration Chromatography}

The protein pellet obtained after saturation with ammonium sulphate between $50 \%$ and $70 \%$ was dissolved in $0.1 \mathrm{M}$ Tris- $\mathrm{HCl}$ buffer and loaded onto a column of Sephadex G-200 $(1.5 \times 24 \mathrm{~cm})$ (Sigma-Aldrich, St Louis, MO) equilibrated with Tris-HCl buffer, $\mathrm{pH} 7.8$. The column was eluted at a flow rate of $60 \mathrm{~mL} / \mathrm{h}$ with a $1: 1$ volume gradient from $0.1 \mathrm{M}$ to $1 \mathrm{M} \mathrm{NaCl}$ in the same buffer. From the elution profile, it was observed that the protease was eluted as a well-resolved single peak of caseinase activity coinciding with a single protein peak at a $\mathrm{NaCl}$ concentration of $0.6 \mathrm{M}$. Fractions (19-23) with high protease activities were pooled, dialyzed, and concentrated by lyophilization (Lyophilizer, Vertisis, South Africa) and used for further studies.

\section{Sodium Dodecyl Sulphate Polyacrylamide Gel Electrophoresis}

After Sephadex G-200 column chromatography, the fractions (19-23) showing the highest specific activity were dialyzed, lyophilized, and then subjected to sodium dodecyl sulphate polyacrylamide gel electrophoresis (SDS-PAGE). The SDS-PAGE was performed according to Laemmli ${ }^{10}$ using $10 \%$ acrylamide.

\section{Analytical Methods}

\section{Determination of Alkaline Protease Activity}

Alkaline protease activity was determined by a modified procedure based on the method of Tsuchida et al. ${ }^{11}$ One protease unit is defined as the amount of enzyme that releases $1 \mu \mathrm{g}$ of tyrosine per $\mathrm{mL}$ per minute under the above assay conditions.

\section{Protein Assay}

Protein was measured by the method of Lowry et $\mathrm{al}^{12}$ with bovine serum albumin (BSA) as the standard. The concentration of protein during purification studies was calculated from the absorbance at $280 \mathrm{~nm}$.

\section{Characterization of Purified Enzyme}

Effect of pH on Purified Enzyme Activity and Stability

The activity of the crude and purified protease was measured at different $\mathrm{pH}$ values in the absence and presence of $10 \mathrm{mM} \mathrm{CaCl}$. The $\mathrm{pH}$ was adjusted using the following buffers $(0.05 \mathrm{M})$ : phosphate $(\mathrm{pH} 5.0-7.0)$, Tris- $\mathrm{HCl}(\mathrm{pH} 8.0)$, and glycine- $\mathrm{NaOH}(\mathrm{pH}$ 9.0-12.0). Reaction mixtures were incubated at $40^{\circ} \mathrm{C}$ for $30 \mathrm{~min}$ utes, and the activity of the enzyme was measured.

The purified enzyme was diluted in different relevant buffers $(\mathrm{pH} 5.0-12.0)$ and incubated at $40^{\circ} \mathrm{C}$ for 2 and 20 hours for enzyme stability. The relative activity at each exposure was measured as per assay procedure.

\section{Effect of Temperature on Enzyme Activity and Stability}

The activity of the crude and purified enzyme was determined by incubating the reaction mixture at different temperatures ranging from $30^{\circ} \mathrm{C}$ to $90^{\circ} \mathrm{C}$ in the absence and presence of $10 \mathrm{mM} \mathrm{CaCl}_{2}$ for 30 minutes.

To determine the enzyme stability with changes in temperature, purified enzyme was incubated at differ- 


\section{AAPS PharmSciTech 2003; 4 (4) Article 56 (http://www.aapspharmscitech.org).}

ent temperatures $\left(60^{\circ} \mathrm{C}, 70^{\circ} \mathrm{C}\right.$, and $\left.80^{\circ} \mathrm{C}\right)$ in the presence of $10 \mathrm{mM} \mathrm{CaCl}$, and relative protease activities were assayed at standard assay conditions.

\section{Effect of Protease Inhibitors and Chelators on En- zyme Activity}

The effect of various protease inhibitors $(5 \mathrm{mM})$ such as serine inhibitors (phenylmethylsulphonyl fluoride [PMSF] and diisopropyl fluorophosphate [DFP]), cysteine-inhibitors ( $p$-chloromercuric benzoate $[p \mathrm{CMB}]$ and $\beta$-mercaptoethanol $[\beta$-ME], iodoacetate), and a chelator of divalent cations (ethylene diamine tetra acetic acid [EDTA]) were determined by preincubation with the enzyme solution for 30 minutes at $60^{\circ} \mathrm{C}$ before the addition of substrate. The relative protease activity was measured.

\section{Effect of Various Metal Ions on Protease Activity}

The effects of metal ions (eg, $\mathrm{Ca}^{2+}, \mathrm{Mg}^{2+}, \mathrm{Al}^{+3}, \mathrm{Co}^{+2}$, $\mathrm{Cd}^{+2}, \mathrm{Fe}^{+3}, \mathrm{Na}^{+}, \mathrm{Zn}^{2+}, \mathrm{Hg}^{2+}$, and $\left.\mathrm{Cu}^{2+}[5 \mathrm{mM}]\right)$ were investigated by adding them to the reaction mixture. Relative protease activities were measured.

\section{Hydrolysis of Protein Substrates}

Protease activity with various protein substrates including BSA, casein, egg albumin, and gelatin was assayed by mixing $100 \mathrm{ng}$ of the enzyme and $200 \mu \mathrm{L}$ of assay buffer containing the protein substrates $(2 \mathrm{mg} / \mathrm{mL})$. After incubation at $60^{\circ} \mathrm{C}$ for 30 minutes, the reaction was stopped by adding $200 \mu \mathrm{L}$ of $10 \%$ trichloro acetic acid (TCA) (wt/vol) and allowed to stand at room temperature for 10 minutes. The undigested protein was removed by centrifugation and peptides released were assayed. The specific protease activity towards casein was taken as a control.

\section{Detergent Stability}

The compatibility of PE-11 protease with local laundry detergents was studied in the presence of $10 \mathrm{mM} \mathrm{CaCl}_{2}$ and $1 \mathrm{M}$ glycine. Detergents used were Nirma (Nirma Chemical, India); Henko (Henkel Spic, India); Surf, Surf Excel, Super Wheel, Rin (Hindustan Lever Ltd, India); and Ariel (Procter and Gamble, India). The detergents were diluted in distilled water $(0.7 \% \mathrm{wt} / \mathrm{vol})$ and incubated with protease for 3 hours at $60^{\circ} \mathrm{C}$, and the residual activity was determined. The enzyme activity of a control sample (without any detergent) was taken as $100 \%$.

\section{Washing Test with Protease Preparation}

Application of protease $(5000 \mathrm{U} / \mathrm{mL})$ as a detergent additive was studied on white cotton cloth pieces $(4 \times 4$ $\mathrm{cm})$ stained with blood. The stained cloth pieces were taken in separate flasks. The following sets were prepared and studied:

1.flask with distilled water $(100 \mathrm{~mL})+$ stained cloth (cloth stained with blood)

2.flask with distilled water $(100 \mathrm{~mL})+$ stained cloth (cloth stained with blood) $+1 \mathrm{~mL}$ wheel detergent $(7 \mathrm{mg} / \mathrm{mL})$

3.flask with distilled water $(100 \mathrm{~mL})+$ stained cloth (cloth stained with blood) $+1 \mathrm{~mL}$ wheel detergent $(7 \mathrm{mg} / \mathrm{mL})+2 \mathrm{~mL}$ enzyme solution

The above flasks were incubated at $60^{\circ} \mathrm{C}$ for $15 \mathrm{~min}$ utes. After incubation, cloth pieces were taken out, rinsed with water, and dried. Visual examination of various pieces exhibited the effect of enzyme in removal of stains. Untreated cloth pieces stained with blood were taken as control.

\section{RESULTS AND DISCUSSION}

$B$ subtilis $\mathrm{PE}-11$, maximum growth and maximum enzyme production was observed at 48 hours (Figure 1). The zone of hydrolysis of $B$ subtilis PE-11 on milk agar is shown in Figure 2.

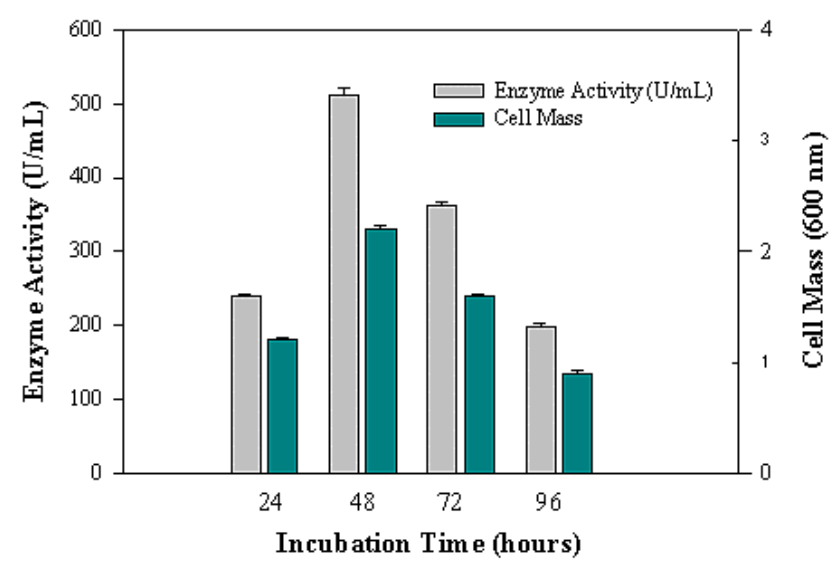

Figure 1. Growth and protease production by $B$ subtilis PE-11. 


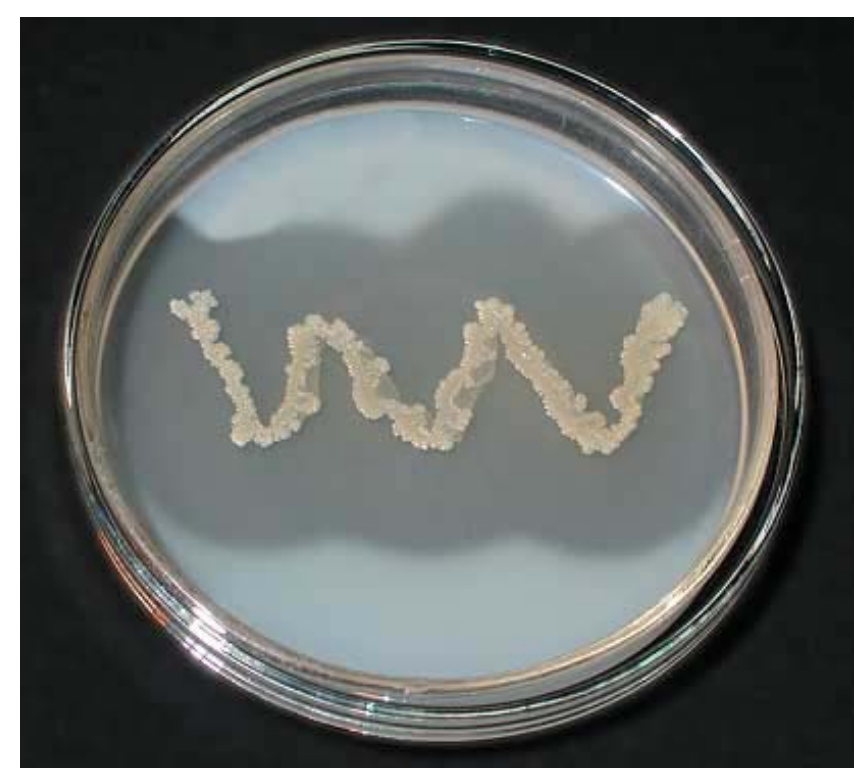

Figure 2. The zone of hydrolysis of $B$ subtilis PE-11 on milk agar.

\section{Purification of Extracellular Protease of B sub- tilis PE-11}

\section{Sephadex G-200 Gel Filtration Chromatography}

The protein pellet obtained after $60 \%$ saturation with ammonium sulphate was dissolved in $0.1 \mathrm{M}$ Tris- $\mathrm{HCl}$ buffer and loaded onto a column of Sephadex G-200 $(1.5 \times 24 \mathrm{~cm})$ equilibrated with Tris- $\mathrm{HCl}$ buffer, $\mathrm{pH}$ 7.8. The elution profile of gel filtration chromatography is shown in Figure 3.

From the elution profile, it was observed that the protease was eluted as a well-resolved single peak of caseinase activity coinciding with a single protein peak at $\mathrm{NaCl}$ concentration of $0.6 \mathrm{M}$. Fractions (19-23) with protease activities were pooled, dialyzed, and concentrated by lyophilization and used for further studies. The summary of purification steps involved for alkaline protease is presented in Table 1.

\section{SDS-PAGE of Culture Filtrate and Purified Pro- tease from $B$ subtilis PE-11}

When the ammonium sulphate precipitation and purified protease were analyzed by SDS-PAGE, 7 bands were observed in the case of the ammonium sulphate precipitation, while purified protease showed a single band, indicating a homogeneous preparation. The molecular weight of the protease was determined by comparison of the migration distances of standard marker proteins. The molecular mass standards were BSA (67 $\mathrm{kd})$, ovalbumin (45 kd), carbonic anhydrase (30 kd), trypsinogen $(24 \mathrm{kd})$, and $\alpha$ - lactalbumin $(14 \mathrm{kd})$ on SDS-PAGE. The molecular weight was determined by interpolation from a linear semilogarithmic plot of relative molecular mass versus the $\mathrm{R}_{\mathrm{f}}$ value (relative mobility). Depending on the relative mobility, the molecular weight of the protein band was calculated to be $15 \mathrm{kd}$, which coincided with the band of $\alpha$ - lactalbumin marker protein.

\section{Characterization of Purified Enzyme \\ pH Optimum and pH Stability}

For the determination of the $\mathrm{pH}$ optimum, phosphate (pH 5.0-7.0), Tris- $\mathrm{HCl}$ ( $\mathrm{pH} 8.0$ ), and glycine- $\mathrm{NaOH}$ (pH 9.0-12.0) buffers were used in the absence and presence of $10 \mathrm{mM} \mathrm{CaCl}_{2}$. The highest protease activity was found to be at $\mathrm{pH} 10.0$ using glycine- $\mathrm{NaOH}$ buffer (Figure 4). These findings are in accordance with several earlier reports showing $\mathrm{pH}$ optima of 10.0-10.5 for protease from Bacillus sp, Thermus aquaticus, Xanthomonas maltophila, and Vibrio metscnikovii. ${ }^{13-16}$ The important detergent enzymes, subtilisin Carlberg and subtilisin Novo or BPN ${ }^{17}$ also showed maximum activity at $\mathrm{pH} 10.5$.

The stability of the purified protease was also determined by the preincubation of the enzyme in various buffers of different $\mathrm{pH}$ values. In the case of 2 hours preincubation group, the enzyme was stable over a broad range of $\mathrm{pH} 8$ to $\mathrm{pH} 11$ (Figure 5). On the other hand, in the case of the 20 hours preincubation group, the enzyme was stable between $\mathrm{pH} 8$ and $\mathrm{pH} 10$. However, in an earlier study, the protease from a Thermus sp strain Rt41 $\mathrm{A}^{18}$ exhibited stability for at least 4 hours over a $\mathrm{pH}$ range of 5 to 10 .

\section{Temperature Optimum and Thermal Stability}

The activity of the crude and purified enzyme was determined at different temperatures ranging from $30^{\circ} \mathrm{C}$ to $90^{\circ} \mathrm{C}$ in the absence and presence of $10 \mathrm{mM} \mathrm{CaCl} 2$. The optimum temperature recorded was at $60^{\circ} \mathrm{C}$ for protease activity. The enzyme activity gradually declined at temperatures beyond $60^{\circ} \mathrm{C}$ (Figure 6). A similar type of result was observed by other investigators where a maximum temperature of $55^{\circ} \mathrm{C}$ was recorded for an alkaline protease from $B$ stearothermophilus AP- $4^{19}$ and $60^{\circ} \mathrm{C}$ for a protease ${ }^{20}$ derived from Bacillus sp B21-2.

The thermal stability of the purified protease was tested at different temperatures of $60^{\circ} \mathrm{C}, 70^{\circ} \mathrm{C}$, and $80^{\circ} \mathrm{C}$ for different periods (50 to 350 minutes) in the presence of 

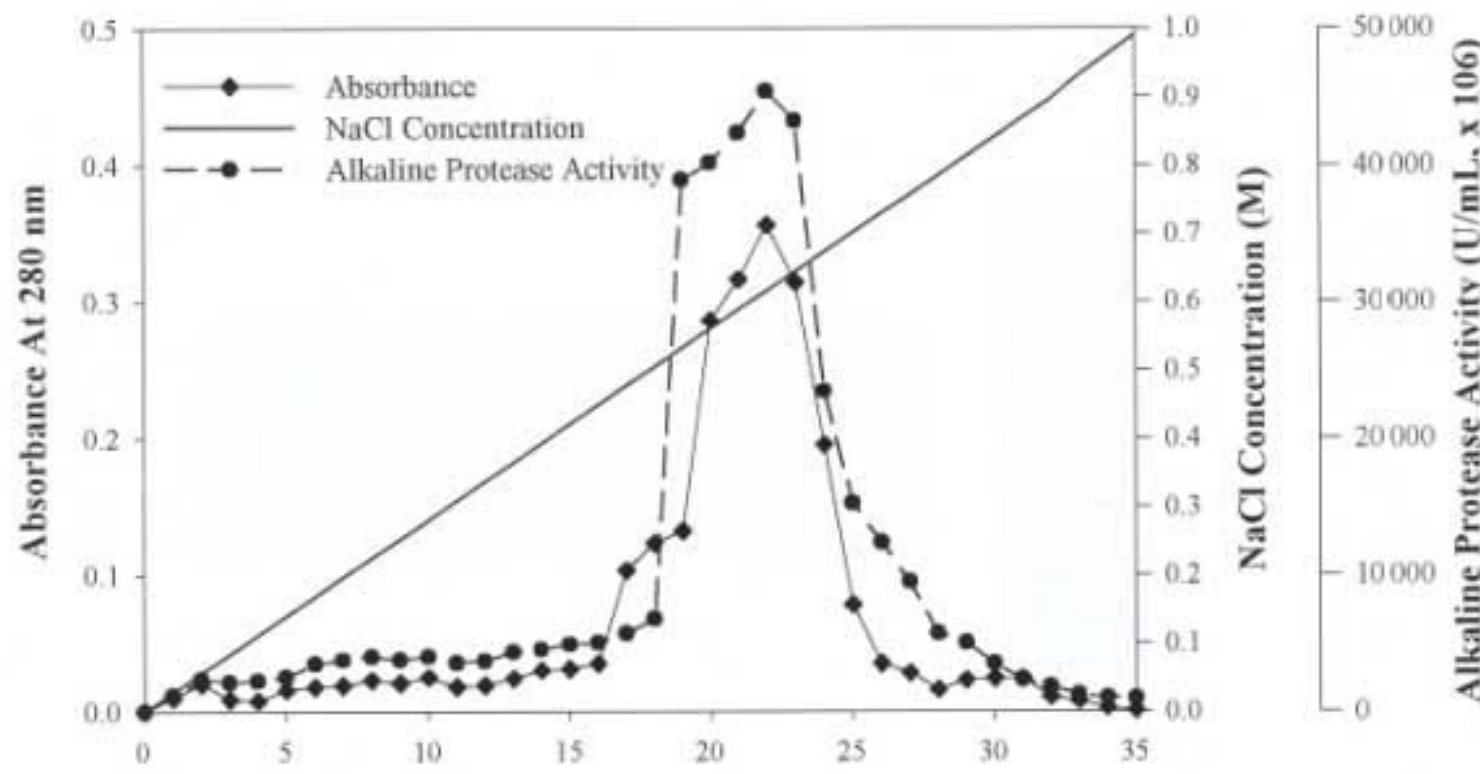

Time (hours)

Figure 3. Elution profile of $B$ subtilis PE-11 protease by Sephadex G-200 column.

Table 1. Summary of Purification Steps of Alkaline Protease From Bacillus subtilis PE-11

\begin{tabular}{lccccc}
\hline Purification Step & $\begin{array}{c}\text { Total Enzyme } \\
\text { Activity (U) }\end{array}$ & $\begin{array}{c}\text { Total Protein } \\
(\mathbf{m g})\end{array}$ & $\begin{array}{c}\text { Specific Activity } \\
(\mathbf{U} / \mathbf{m g})\end{array}$ & Purification Fold & \% Recovery \\
\hline Crude enzyme & 50400 & 4920 & 10.2 & 1.0 & 100 \\
$\begin{array}{l}\left(\mathrm{NH}_{4}\right)_{2} \mathrm{SO}_{4} \text { precipita- } \\
\text { tion, dialyzed }\end{array}$ & 36250 & 3000 & 12.1 & 1.2 & 72.0 \\
Sephadex G-200 & 3760 & 17.6 & 213.6 & 21.0 & 7.5 \\
\hline
\end{tabular}

$10 \mathrm{mM} \mathrm{CaCl}_{2}$. The PE-11 protease had a half life of 250 and less than 50 minutes at $70^{\circ} \mathrm{C}$ and $80^{\circ} \mathrm{C}$, respectively. The enzyme was almost $100 \%$ stable at $60^{\circ} \mathrm{C}$ even after 350 minutes of incubation (Figure 7). Previous reports on thermostability have shown half-lives of $>200$ minutes at $50^{\circ} \mathrm{C}$ and 2 to 22 minutes at $60^{\circ} \mathrm{C}$ for heat stable serine proteases, and half-lives of $3.4 \mathrm{~min}$ utes and 2.4 minutes at $50^{\circ} \mathrm{C}$ have been recorded for subtilisin Carlsberg and subtilisin BPN, respectively. ${ }^{13}$

\section{Effect of Inhibitiors and Chelators}

Inhibition studies primarily give an insight into the nature of an enzyme, its cofactor requirements, and the nature of the active center. ${ }^{21}$ The effect of different inhibitors on the enzyme activity of the purified protease was studied (Table 2). Of the inhibitors tested (at $5 \mathrm{mM}$ concentration), PMSF was able to inhibit the protease completely, while DFP exhibited 94\% inhibition. In this regard, PMSF sulphonates the essential serine residue in the active site of the protease and has been reported to result in the complete loss of enzyme activity. ${ }^{22}$ Our findings were similar to those of Tsuchida et $\mathrm{al}^{11}$ and Yamagata et $\mathrm{al},{ }^{23}$ where the protease was completely inhibited by PMSF. This indicated that it is a serine alkaline protease. In the case of other inhibitors, the protease was not inhibited by EDTA, while a slight inhibition was observed with iodoacetate, $p \mathrm{CMB}$, and $\beta$-ME.

\section{Effect of Metal Ions}

Most of the metal ions tested had a stimulatory effect $\left(\mathrm{Ca}^{2+}, \mathrm{Mg}^{2+}\right.$, and $\left.\mathrm{Mn}^{2+}\right)$ or a slight inhibitory effect 


\section{AAPS PharmSciTech 2003; 4 (4) Article 56 (http://www.aapspharmscitech.org).}

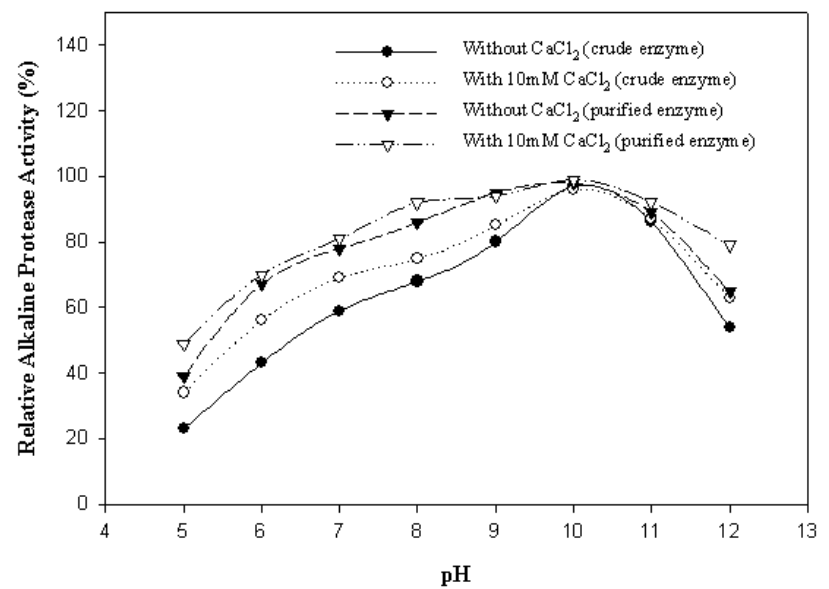

Figure 4. Effect of $\mathrm{pH}$ on the activity of alkaline protease in the presence and absence of $10 \mathrm{mM} \mathrm{CaCl}_{2}$.

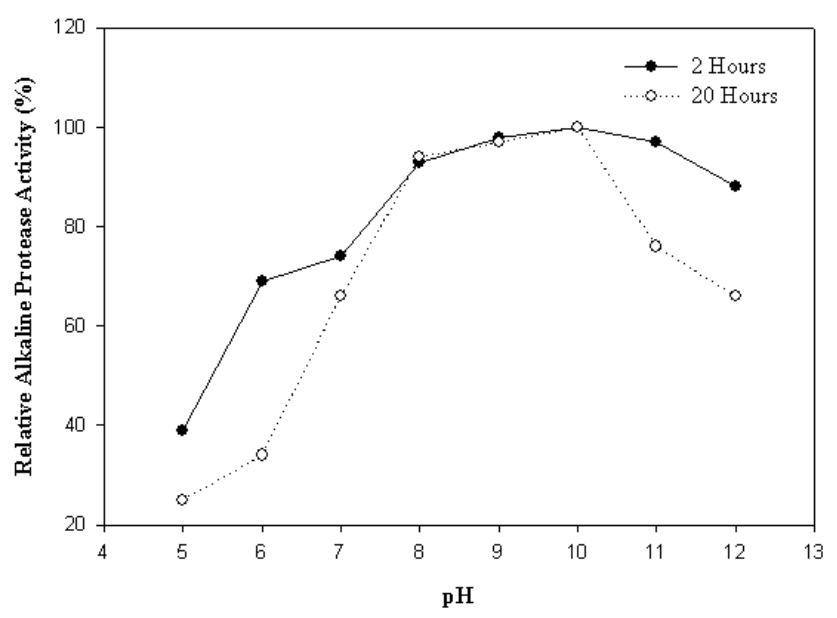

Figure 5. Effect of $\mathrm{pH}$ on the stability of alkaline protease in the presence of $10 \mathrm{mM} \mathrm{CaCl}_{2}$.

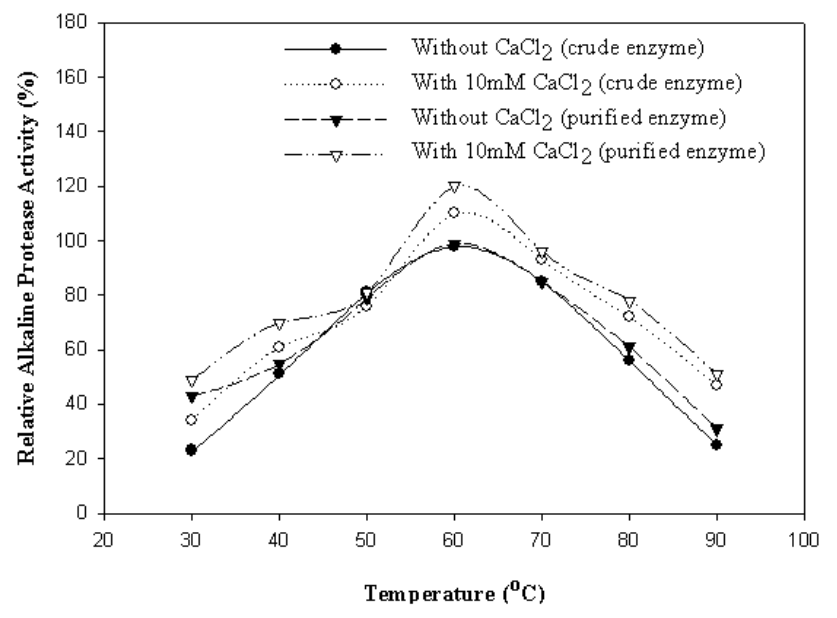

Figure 6. Effect of temperature profiles on the activity of alkaline protease in the presence and absence of $10 \mathrm{mM} \mathrm{CaCl}_{2}$. (other ions) on enzyme activity (Table 3). Some of the metal ions such as $\mathrm{Ca}^{2+}, \mathrm{Mg}^{2+}$, and $\mathrm{Mn}^{2+}$ increased and stabilized the protease activity of the enzyme; this is possible because of the activation by the metal ions. These cations also have been reported to increase the thermal stability of other Bacillus alkaline proteases. ${ }^{24-}$ ${ }^{25}$ These results suggest that concerned metal ions apparently protected the enzyme against thermal denaturation and played a vital role in maintaining the active confirmation of the enzyme at high temperatures. ${ }^{26-28}$ Other metal ions such as $\mathrm{Zn}^{2+}, \mathrm{Cu}^{2+}, \mathrm{Hg}^{2+}, \mathrm{Co}^{2+}, \mathrm{Na}^{+}$, $\mathrm{Cd}^{2+}, \mathrm{Al}^{3+}$, and EDTA did not shown any appreciable effect on enzyme activity.

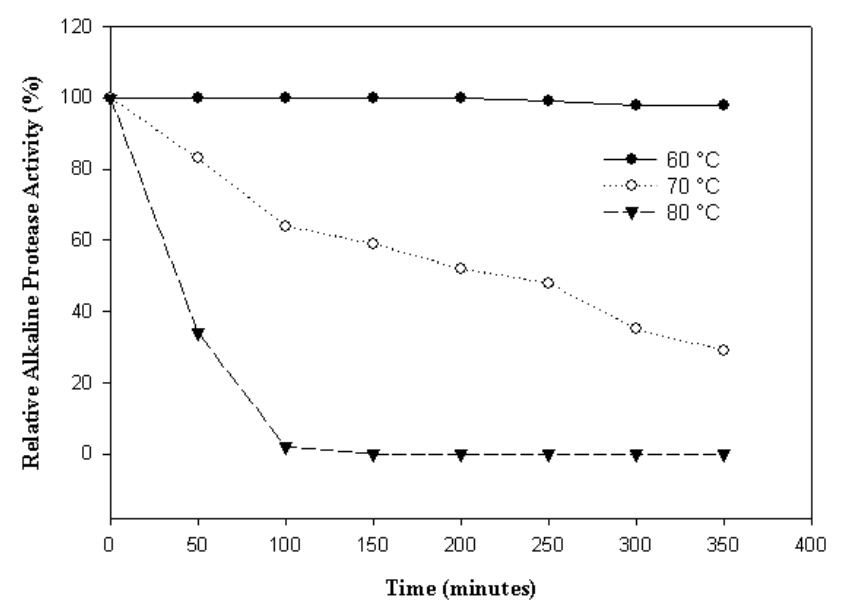

Figure 7. Effect of temperature on the stability of the enzyme in the presence of $10 \mathrm{mM} \mathrm{CaCl}_{2}$.

Table 2. Effect of Protease Inhibitors/Chelators on the Enzyme Activity*

\begin{tabular}{cc}
\hline $\begin{array}{c}\text { Inhibitor/Chelator } \\
(\mathbf{5 m M})\end{array}$ & $\begin{array}{c}\text { \% Relative Enzyme } \\
\text { Activity }\end{array}$ \\
\hline Control & 100 \\
$\beta-\mathrm{ME}$ & 81 \\
Iodoacetate & 90 \\
$p \mathrm{CMB}$ & 85 \\
PMSF & 00 \\
DFP & 06 \\
EDTA & 106 \\
\hline
\end{tabular}

* $\beta$-ME indicates $\beta$-mercaptoethanol; DFP, diisopropyl fluorophosphate; EDTA, ethylene diamine tetra acetic acid; $p C M B$, $p$-chloromercuric benzoate; and PMSF, phenylmethyl sulphonyl fluoride. 


\section{AAPS PharmSciTech 2003; 4 (4) Article 56 (http://www.aapspharmscitech.org).}

Table 3. Effect of Various Metal Ions on Alkaline Protease Activity*

\begin{tabular}{cc}
\hline Metal Ions (5mM) & $\begin{array}{c}\text { Residual Alkaline Protease } \\
\text { Activity (\%) }\end{array}$ \\
\hline $\mathrm{Control}$ & 100 \\
$\mathrm{Zn}^{2+}\left(\mathrm{ZnCl}_{2}\right)$ & 95 \\
$\mathrm{Cu}^{2+}\left(\mathrm{CuCl}_{2}\right)$ & 96 \\
$\mathrm{Mg}^{2+}\left(\mathrm{MgCl}_{2}\right)$ & 116 \\
$\mathrm{Hg}^{2+}\left(\mathrm{HgCl}_{2}\right)$ & 93 \\
$\mathrm{Co}^{2+}\left(\mathrm{CoCl}_{2}\right)$ & 92 \\
$\mathrm{Ca}^{2+}\left(\mathrm{CaCl}_{2}\right)$ & 135 \\
$\mathrm{Na}^{+}\left(\mathrm{NaCl}^{2}\right)$ & 98 \\
$\mathrm{Cd}^{2+}\left(\mathrm{CdCl}_{2}\right)$ & 92 \\
$\mathrm{Al}^{3+}\left(\mathrm{AlCl}_{3}\right)$ & 97 \\
$\mathrm{EDTA}^{2+}$ & 99 \\
$\mathrm{Mn}^{2+}\left(\mathrm{MnCl}_{2}\right)$ & 108 \\
\hline *EDTA indicates ethylene diamine tetra acetic acid.
\end{tabular}

Table 4. Alkaline Protease Activity Against Different Natural Substrates*

\begin{tabular}{cc}
\hline Substrate (2 $\mathbf{~ m g} / \mathbf{m L})$ & $\begin{array}{c}\text { Relative Enzyme Activity } \\
(\mathbf{\%})\end{array}$ \\
\hline Casein & 100 \\
BSA & 41 \\
Egg albumin & 23 \\
Gelatin & 9 \\
\hline
\end{tabular}

*BSA indicates bovine serum albumin.

\section{Hydrolysis of Protein Substrates}

When assayed with native proteins as substrates, the protease showed a high level of hydrolytic activity against casein and poor to moderate hydrolysis of BSA and egg albumin, although the hydrolysis was hardly observed with gelatin (Table 4).

\section{Compatibility with Detergents}

Besides $\mathrm{pH}$, a good detergent protease is expected to be stable in the presence of commercial detergents. The PE-11 protease showed excellent stability and compatibility in the presence of locally available detergents (Nirma, Wheel, Henko, Surf, Surf Excel, Ariel, and Rin).
Protease from $B$ subtilis PE-11 showed stability and compatibility with a wide range of commercial detergents at $60^{\circ} \mathrm{C}$ in the presence of $\mathrm{CaCl}_{2}$ and glycine as stabilizers. Our protease showed good stability and compatibility in the presence of Wheel followed by Surf excel (Table 5). The enzyme retained more than $50 \%$ activity with most of the detergents tested even after 3 hours incubation at $60^{\circ} \mathrm{C}$ after the supplementation of $\mathrm{CaCl}_{2}$ and glycine. Bhosale et $\mathrm{al}^{29}$ reported high activity alkaline protease from $C$ coronatus showing compatibility at $50^{\circ} \mathrm{C}$, in the presence of $25 \mathrm{mM} \mathrm{CaCl}_{2}$, with a variety of commercial detergents. Bhosale et al reported $16 \%$ activity in Revel, $11.4 \%$ activity in Aerial, and $6.6 \%$ activity in Wheel. Comparing these results, the $B$ subtilis PE-11 enzyme was significantly more stable in commercial detergents.

The compatibility of alkaline protease was studied with Wheel in the presence of $10 \mathrm{mM} \mathrm{CaCl} 2$ and $1 \mathrm{M}$ glycine for different periods $(0.5$ to 3 hours $)$ at $60^{\circ} \mathrm{C}$. The enzyme retained about $67 \%$ activity after 1.5 hours in the presence of Wheel at $60^{\circ} \mathrm{C}$ and was almost inactivated after 3 hours in the absence of any stabilizer (Figure 8). However, the addition of $\mathrm{CaCl}_{2}(10 \mathrm{mM})$ and glycine $(1 \mathrm{M})$, individually and in combination, was very effective in improving the stability, where it retained $52 \%$ activity even after 3 hours.

As the protease produced by our isolate $B$ subtilis PE11 was stable over a wide range of $\mathrm{pH}$ values and temperatures and also showed compatibility with various commercial detergents tested in the presence of $\mathrm{CaCl}_{2}$ and glycine, it was used as an additive in detergent, to check the contribution of the enzyme in improving the washing performance of the detergent. The supplementation of the enzyme preparation in detergent (ie, Wheel) could significantly improve the cleansing of the blood stains (Figure 9).

\section{CONCLUSION}

The alkaline protease isolated from $B$ subtilis $\mathrm{PE}-11$ is a thermostable serine protease. It is stable at alkaline $\mathrm{pH}$, at high temperatures, and in the presence of commercial detergents and is compatible with commercial and local detergents. These properties indicate the possibilities for use of the protease in the detergent industry. This enzyme can be exploited commercially. 
AAPS PharmSciTech 2003; 4 (4) Article 56 (http://www.aapspharmscitech.org).

Table 5. Compatibility of Alkaline Protease Activity from Bacillus subtilis PE-11 With Commercial Detergents in the Presence of $10 \mathrm{mM} \mathrm{CaCl}_{2}$ and Glycine at $60^{\circ} \mathrm{C}$

\begin{tabular}{ccccccccc}
\hline \multicolumn{1}{c}{ Relative Residual Alkaline Protease Activity (\%) } \\
\hline Time (hour) & Control & Nirma & Wheel & Henko & Surf & Surf Excel & Ariel & Rin \\
\hline 0.0 & 100 & 100 & 100 & 100 & 100 & 100 & 100 & 100 \\
0.5 & 96 & 90 & 95 & 92 & 91 & 93 & 88 & 87 \\
1.0 & 94 & 87 & 92 & 89 & 87 & 90 & 85 & 83 \\
1.5 & 91 & 85 & 89 & 86 & 83 & 87 & 82 & 81 \\
2.0 & 87 & 79 & 82 & 79 & 75 & 80 & 74 & 72 \\
2.5 & 80 & 69 & 73 & 68 & 63 & 70 & 61 & 59 \\
3.0 & 76 & 58 & 65 & 58 & 51 & 56 & 52 & 53 \\
\hline
\end{tabular}

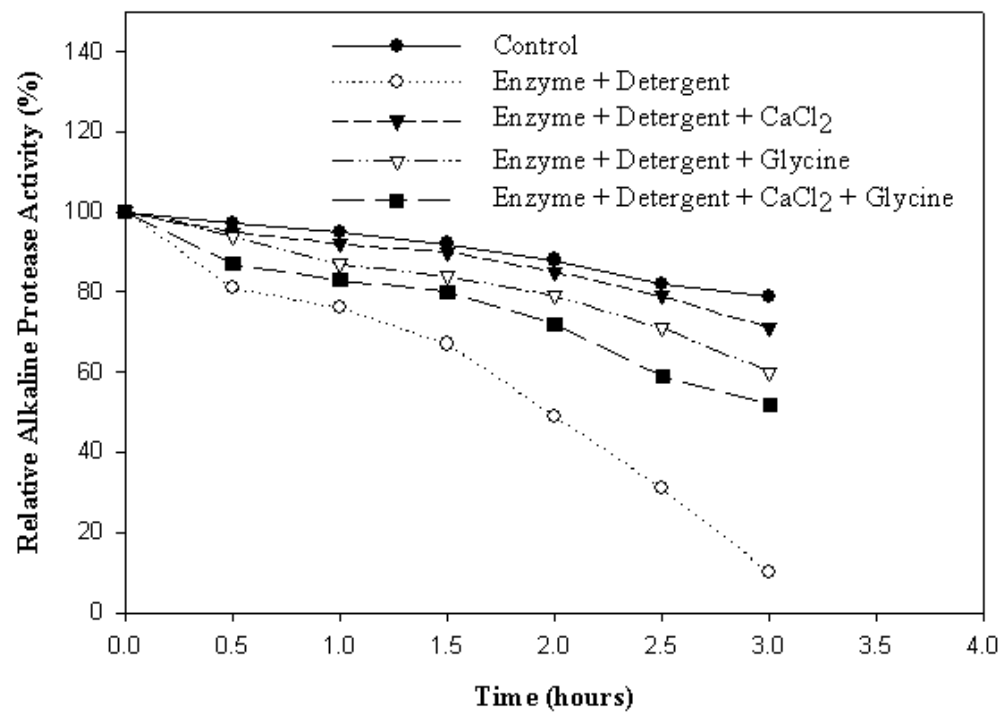

Figure 8. Compatibility of alkaline protease with Wheel in the presence of $10 \mathrm{mM} \mathrm{CaCl}_{2}$ and $1 \mathrm{M}$ glycine at $60^{\circ} \mathrm{C}$.

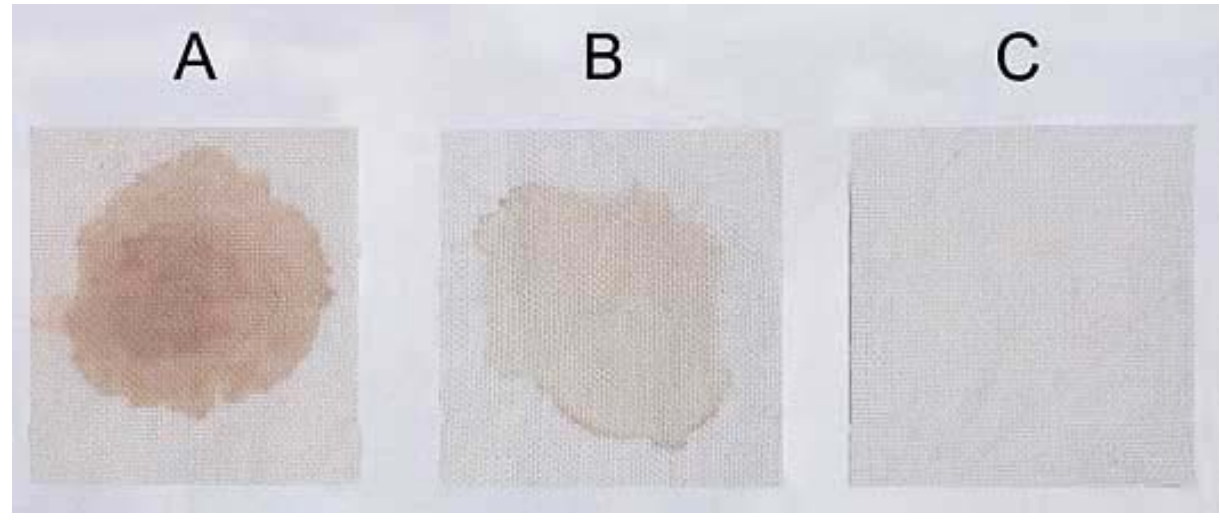

Figure 9. Washing performance of alkaline protease from $B$ subtilis PE-11 in the presence of detergent (Wheel). (A) cloth stained with blood; (B) blood-stained cloth washed with detergent only; and (C) blood-stained cloth washed with detergent and enzyme. 


\section{AAPS PharmSciTech 2003; 4 (4) Article 56 (http://www.aapspharmscitech.org).}

\section{ACKNOWLEDGEMENTS}

Dr. Kunamneni Adinarayana is thankful to Andhra University, Visakhapatnam, India, for providing the infrastructure facilities for this study.

\section{REFERENCES}

1. Ward OP. Proteolytic enzymes. In: Blanch HW, Drew S, Wang DI, eds. Comprehensive Biotechnology. Vol 3. Oxford, UK: Pergamon Press; 1985:789-818.

2. Kalisz HM. Microbial Proteinases. Adv Biochem Eng Biotechnol. 1988;36:1-65.

3. Beg KB, Sahai V, Gupta R. Statistical media optimization and alkaline protease production from Bacillus mojavensis in a bioreactor. Process Biochem. 2003;39:203-209.

4. Ellaiah P, Adinarayana K, Rajyalaxmi P, Srinivasulu B. Optimization of process parameters for alkaline protease production under solid state fermentation by alkalophilic Bacillus sp. Asian J Microbiol Biotechnol Environ Sci. 2003;5:49-54.

5. Adinarayana K, Ellaiah P. Production of alkaline protease by immobilized cells of alkalophilic Bacillus sp. J Sci Ind Res (India). 2003;62:589-592.

6. Moreira KA, Porto TS, Teixeira MFS, Porto ALF, Lima Filho JL. New alkaline protease from Nocardiopsis sp: partial purification and characterization. Process Biochem. 2003. In press.

7. Griffin HL, Greene RV, Cotta MA. Isolation and characterization of an alkaline protease from the marine shipworm bacterium. Curr Microbiol. 1992; 24: 111-117.

8. Ellaiah P, Adinarayana K, Pardasaradhi SV, Srinivasulu B. Isolation of alkaline protease producing bacteria from Visakhapatnam soil. Ind J Microbiol. 2002;42:173-175.

9. Sneath HAP, Halt GJ, eds. Bergey's Manual of Systematic Bacteriology. Vol 2. Baltimore, MD: Williams and Wilkins; 1986.

10. Laemmli UK. Cleavage of structural proteins during the assembly of the head of bacteria phage T4. Nature. 1971;227:680685 .

11. Tsuchida O, Yamagota Y, Ishizuka J, Arai J, Yamada J, Takeuchi M, Ichishima E. An alkaline proteinase of an alkalophilic Bacillus sp. Curr Microbiol. 1986;14:7-12.

12. Lowry OH, Rosebrough NJ, Farr AL, Randall RL. Protein measurement with the folin phenol reagent. J Biol Chem. 1951;193:265-273.

13. Durham DR, Stewart DB, Stelwag EG. Novel alkaline and heat stable proteases from alkalophilic Bacillus species strain GX 6638. J Bacteriol. 1987;169:2762-2768.

14. Matsuzawa H, Tokugawa K, Hamaoki M, Mizoguchi M, Taguchi $\mathrm{H}$, Terada I, Kwon S, Ohta T. Purification and characterization of agualysin I (thermophilic alkaline serine protease) produced by Thermus aquaticus YT-I. Eur J Biochem. 1988;171:441447.

15. Debette J. Isolation and characterizaion of an extracellular protease produced by a soil strain of Xanthomonas maltophila. Curr Microbiol. 1991;22:85-90.

16. Kwon YT, Kim JO, Moon SY, Lee HH, Rho HM. Extracellular alkaline protease from alkalophilic Vibrio metschnikovi strain RH 530. Biotechnol Lett. 1994;16:413-418.
17. Horikoshi K. Enzymes of alkalophiles. In: Microbial Enzymes and Biotechnology. 2nd ed. St Louis, MO: Elsevier Applied Science; 1990:275-294.

18. Peek K, Daniel RM, Monk C, Parker L, Coolbear T. Purification and characterization of a thermostable proteinase isolated from Thermus species strain Rt41A. Eur J Biochem. 1992;207:1035-1044.

19. Dhandapani R, Vijayaragavan R. Production of a thermophilic extracellular alkaline protease by Bacillus stearothermophilus AP4. World J Microbiol Biotechnol. 1994;10:33-35.

20. Fujiwara N, Yamamoto K. Production of alkaline protease in low-cost medium by alkalophilic Bacillus species and properties of the enzyme. J Ferment Technol. 1987;65:345-348.

21. Sigma DS, Mooser G. Chemical studies of enzyme active sites. Annu Rev Biochem. 1975;44:889-931.

22. Gold AM, Fahrney D. Sulfonyl fluorides as inhibitors of esterases. II. Formation and reactions of phenylmethane sulfonyl alpha-chymotrypsin. Biochem. 1964;3:783-791.

23. Yamagata Y, Ichishima E. A new alkaline proteinase with PI 2.8 from alkalophilic Bacillus species. Curr Microbiol. 1989;19:259-264.

24. Rahman RNZA, Razak CN, Ampon K, Basri M, Yunus WMZW, Salleh AB. Purification and characterization of a heat stable alkaline protease from Bacillus stearothermophilus $\mathrm{F} 1$. Appl Microbiol Biotechnol. 1994;40:822-827.

25. Paliwal N, Singh SP, Garg SK. Cation-induced thermal stability of an alkaline protease from a Bacillus species. Biores Technol. 1994;50:209-211.

26. Pan T, Lin S. Fermentative production of alkaline protease as detergent additive. J Chinese Biochem Soc. 1991;20:49-60.

27. Steele DB, Fiske MJ, Steele BP, Kelley VC. Production of a low molecular weight, alkaline active, thermostable protease by a novel spiral-shaped bacterium. Enzyme Microb Technol. 1992;14:358-360.

28. Donaghy JA, Mckay AM. Production and properties of an alkaline protease by Aureobasidium pullulans. J Appl Bacteriol. 1993;74:662-666.

29. Bhosale SH, Rao MB, Deshpande VV, Srinivasan MC. Thermostability of high-activity alkaline protease from Conidiobolus coronatus (NCL 86.8.20). Enzyme Microb Technol. 1995;17:136139. 